\title{
On the Optimal Strategy of the Participating Subjects in the Electronic Payment Market in China
}

\author{
Qiudan Xing \\ International Business School, Shaanxi Normal University \\ Xi'an City
}

\author{
Sijia Liu \\ International Business School, Shaanxi Normal University \\ Xi'an City
}

\author{
Jia Hei \\ International Business School, Shaanxi Normal University \\ Xi'an City
}

\begin{abstract}
This paper focuses on the development and innovation of third-party electronic payment services and modes and the development and current situation of online banking as well as the regulatory policies of financial regulators. From the perspective of interest concerns of major players in the electronic payment market, The main conclusions are as follows: thirdparty payment service providers should give full play to the ability and advantage of payment mode innovation and service innovation; commercial banks should fully and accurately grasp the characteristics and trends of the development of Internet finance and change the modes of product development, business development and marketing advertising. Financial supervision should be conducted in a timely and effective manner, prevent financial confusion and systemic financial risks, ensure standardized operation, orderly competition and service entities, and encourage innovative Internet financial development. This paper analyzes the current situation of electronic payment market in our country from a unique perspective, and gives some concrete suggestions for participants' future development by analyzing, which has certain reference value for the better development of electronic payment market.
\end{abstract}

Keywords-Multi-subject participation; Electronic payment; Optimal strategy

\section{INTRODUCTION}

With the continuous emergence of electronic payment innovation model, electronic payment service scene expands and popularization, the era of electronic payment without cash is accelerating, the new electronic payment service such as internet payment and mobile payment keeps the fast developing momentum, and the products and services are developing rapidly, efficiently and conveniently. According to
China Internet Network Information Center (CNNIC) released the 41st "China Internet Development Status Statistics Report", as of December 2017, China's online payment users up to 531 million, mobile online payment users have reached 527 million, rapid growth, mobile internet dominance, Mobile payment to the fast penetration of the offline payment field, greatly enriched the payment scene, Internet citizens in supermarkets, convenience stores and other offline entities shop using mobile phone online payment settlement habits further deepen, already $65.5 \%$ of Internet citizens online shopping in the physical shop using mobile phone payment settlement, has fundamentally profoundly changed people's consumption, payment, The daily habits of transfer, payment and so on, Non-cash society is accelerating

\section{Electronic Payment Methods AND CATEgories}

With the 2011101 Third party payment enterprises and mobile operators received the People's Bank of China's "payment business License" licence, the traditional financial payment services to third-party payment service providers opened the door, and gradually formed a diverse, complex pattern of electronic payment service market. And the means of electronic payment services, such as third party online payment mobile payment, POS payment, ATM payment, prepaid card and micro-letter red envelope payment and so on also presents a rich variety of situation; The application of electronic payment service has gradually expanded to internet financial services from the application of internet shopping and living payment, Farmers market and other aspects of life, gradually become a habit of people's daily life, the current stage of China's main popular electronic payment methods as shown in table 1 . 
TABLE I. CURRENT MAJOR ELECTRONIC PAYMENT METHODS IN CHINA

\begin{tabular}{|c|c|c|c|}
\hline $\begin{array}{l}\text { Main types of } \\
\text { electronic payment }\end{array}$ & \multicolumn{2}{|c|}{ method of payment/ ways } & The main payment scenario \\
\hline $\begin{array}{l}\text { Online banking to } \\
\text { pay }\end{array}$ & \multicolumn{2}{|c|}{ Bank internet payment } & $\begin{array}{l}\text { Online scene } \\
\text { Both } \mathrm{O} 2 \mathrm{O} \text { scenes }\end{array}$ \\
\hline mobile bank & \multicolumn{2}{|c|}{$\begin{array}{l}\text { Mainly remote internet payment; Individual mobile phone banks have } \\
\text { two-dimension code payment, NFC payment, photon payment }\end{array}$} & $\begin{array}{l}\text { Online scene } \\
\text { Less } \mathrm{O} 2 \mathrm{O} \text { scenes }\end{array}$ \\
\hline Bank card Payment & \multicolumn{2}{|c|}{ Offline billing payment, mobile card machine payment } & $\begin{array}{l}\text { Offline scene, with reverse } \mathrm{O} 2 \mathrm{O} \\
\text { scene }\end{array}$ \\
\hline $\begin{array}{l}\text { Third-party internet } \\
\text { payment }\end{array}$ & \multicolumn{2}{|c|}{$\begin{array}{l}\text { Alipay, Tenpay, Silver merchants, Quick money, Remittance to the } \\
\text { world, Yi Bao payment, IPS, Loop payment, CICC payment, And } \\
\text { package payment, First letter easy to pay, etc. }\end{array}$} & Online scene \\
\hline \multirow{4}{*}{$\begin{array}{l}\text { Third-party mobile } \\
\text { payment }\end{array}$} & Alipay & $\begin{array}{c}\text { Balance payment } \\
\text { Two-dimensional code sweep code } \\
\text { Payment } \\
\text { Bar code Payment } \\
\text { Fingerprint payment }\end{array}$ & \multirow{4}{*}{$\begin{array}{l}\text { Online scene、O2O scenes and } \\
\text { Offline scene across the line } \\
\text { under the limit of the payment } \\
\text { scene diversity. Can carry out } \\
\text { mobile shopping, mobile phone } \\
\text { charge, online shopping clearing, } \\
\text { buy, takeout, travel, mobile end to } \\
\text { buy movie tickets, etc. }\end{array}$} \\
\hline & Wechat payment & $\begin{array}{l}\text { Change payment } \\
\text { two dimensional code sweep code pay } \\
\text { stripes pay } \\
\text { fingerprint pay }\end{array}$ & \\
\hline & $\begin{array}{l}\text { Apple Pay } \\
\text { Huawei Pay } \\
\text { Samsung Pay } \\
\text { Mi Pay }\end{array}$ & $\begin{array}{l}\text { NFC Near Field Payments } \\
++ \\
\text { Fingerprint payment }\end{array}$ & \\
\hline & \multicolumn{2}{|c|}{$\begin{array}{l}\text { Tenpay, Jingdong payment, Baidu wallet, Union Pay payment, Union } \\
\text { Pav online bavment. Ouick monev }\end{array}$} & \\
\hline
\end{tabular}

\section{KEY PlAYERS IN CHINA'S ELECTRONIC PAYMENT MARKET}

In the early stage of E-commerce development, online banking is the only option for electronic payment, internet shopping, electronic transfer and so on must be done through online banking, but with the rise of third-party payments and the continued innovation of payment patterns led by Thirdparty payments and the continuous expansion of payment scenarios, such as supermarkets, hospitals, farmers ' markets, and even individual mobile vendors, both begin to accept the two-dimensional code sweep code payment; There is a sweep of the two-dimensional code to pay, others sweep my twodimensional code payment, business sweeping code payment, such as payment methods, the diversity of application scenarios are reflected incisively and vividly; Meanwhile, mobile payment application platform has been on-line "micro-letter
Red Envelopes", "Alipay Five Blessing" and other innovative models, to social as the breakthrough point of continuous activation, segmentation and mobile payment market, making the public users more inclined to pay treasure, micro-letter payment for the representative of the Third-party payment platform to complete the network purchase, transfer fees and other services. Whether it is the number of users, payment amount, user preferences and other aspects show that the thirdparty payment services are increasingly favored by consumers of the development trend, and gradually occupy the leading position.

Online banking plays an important role in the early development of electronic payment market in China, and the net bank that the user must use to carry on the net purchase and transfer. When shopping online, you should jump from the shopping page to the Net Silver page, enter the account to log 
in, most of the time must also use the Net Silver U shield to enter the payment page to complete the follow-up payment operation, cross-bank transfer also charge fees, which makes many users are not satisfied with the salient feature is higher security price but not convenient, For ordinary consumers, the threshold is too high. At the same time, because the bank in the development of electronic payment focus on security, ignoring the user experience, so online banking web design, mobile phone bank app Design user experience is generally poor, and the limited cooperation between banks, users use mobile banking, different bank cards need to download different app, This is very inconvenient for users. In addition, because its electronic payment business is not its core business, the power of its investment has certain limitations, making the online banking application scene is very single, just online scene, can not be compared with the third party payment. The third party payment service of Internet enterprises and the Internet bank in many business, also from the initial cooperation relationship to fierce competition.

At the same time, the third party payment service mode of Internet enterprises is continuously subversive innovation, such as the third party payment model, balance treasure, electric credit loan, peer-to-peer network lending, two-dimensional code sweep code to pay the financial supervision has been constantly brought vibration, controversy and confusion, regulatory policy also between the prohibition and allow the lingering. No rules. Radius, the development of electronic payment industry is also inseparable from supervision, financial supervision should ensure the healthy development of payment institutions, but also ensure that the third party Internet payment enterprises do not touch the legal bottom line, does not cause systemic financial risks. Regulation in electronic payments, which is still evolving, is often regulated by innovation, too tightly regulated and stifling innovation, which is detrimental to the development of electronic payment markets. There is no precedent, only in the continuous groping forward. There are often divergent views on a new policy, which poses new challenges to financial regulation.

\section{SugGestions ON THE CHOICE OF BeSt STRATEGIES FOR PARTICIPATING PARTIES IN ELECTRONIC PAYMENT MARKET}

Through paying attention to the development and innovation course of the third party electronic payment service and mode, collecting and analyzing the innovation case of the third party electronic payment, and the corresponding countermeasure of the Internet bank, the regulation policy developing of the financial supervision institution, the competition and cooperation in the electronic payment market of the multi subject participation, The contradictions such as innovation and supervision are deeply analyzed and explored, which try to provide valuable reference suggestions for the future strategy choice of the participating subjects.

\section{A. Suggestions on third party payments for future development strategies}

The rapid development of the third party payment industry has benefited from the huge population and market size, the fast internet trend, especially the rise of E-commerce and the rapid development of internet finance, as well as the easy regulation to encourage innovation. The success of the third party Internet payment enterprise stems from its always putting the user experience first, Alipay guarantee service, balance treasure, fast payment, two-dimensional code sweep code payment, micro-letter red envelopes and other payment products and services to the innovation of the user has a new, convenient payment experience, the third party payment service market has become one of the hottest areas of internet finance. However, with the tightening of financial supervision and the gradual reduction of the policy dividend, the competition has been squeezing the profits of the industry, the third party payment growth has slowed down and the market pattern is difficult to change. Third-party payment service providers should seek breakthroughs in the areas of multiple financial services, new consumer ecology, cross-border electronic payment services, and deep vertical industries.

After many years of accumulation, the third party payment service provider has already had a large number of trade and personal transaction data, and should vigorously carry out the multiple financial services based on payment data in the field of credit and financial management. Payment as the basic service of finance, naturally has the advantage of cutting into other financial services, the payment of data accumulated by the exchange, with real, high-frequency and high-quality features, can be used as a necessary supplement to financial transaction data, thus enriching the data dimension, providing precision marketing, credit rating and financial product promotion and other value-added services. At the same time in the mobile Internet development trend, every scene in the public life will become the entry point of the Internet, fast, convenient, accurate, become the Internet payment services in the offline scene of the basic requirements, which requires third-party payment service providers to in-depth understanding of the user's pain point and unmet needs as the starting points, Innovation layout scene business, to find a solid foothold in the market to carry out the rapid development of high-frequency scene, the construction of new consumer ecological circle. We should deeply enrich the existing 
advantageous resources and improve the service content and quality of the ecosystem by continuously enriching the strategic cooperation, and promote the deployment of the ecosystem in the mobile end. To achieve the core capabilities of mobile Internet platform construction and operation, around the "platform operation + Application payment scenario + Business Services", to build platform and application-centered operating service system, the completion of China's leading to pay a comprehensive service platform.

\section{B. Suggestions on the future development strategy of Internet banking}

Facing the increasingly fierce cross-border competition in the Internet field, commercial banks should fully and accurately grasp the characteristics and trends of internet financial development, give full play to the advantages of full function, mature and stable operation, strong risk control ability, as well as professional, security and offline landing in payment and settlement field, In a number of business segments to do deep through the payment settlement services, and actively create a professional comprehensive financial solutions to strengthen the bank to provide corporate customers with payment settlement services in the field of strong position, while efforts to provide enterprises with more convenient electronic remittance and settlement services; As a credit intermediary to provide a full range of transaction capital supervision services to solve the mutual trust between the two parties, and strive in housing transactions, bulk trading and other professional markets to form a first-onset and comparative monopoly advantage.

With internet users as the center to build "financial + life" service platform, the use of Internet technology to integrate electronic channels, and actively use the concept of direct banking, to provide users with independent of the physical network Service system; Seize the development of mobile payment opportunities, combined with the popularity of smart phones and internet users to move to the mobile end of the trend of change, Mobile Banking and micro-credit banks should be actively promoted, to promote, to create a "convenient, safe, interactive, fun" Mobile client, the channel end includes smart phone clients, tablet client, mobile browser Web version, micro-letter, Alipay wallet, etc., will be from customer application scenarios, localized life services and interactive services from the perspective, to create " Mobile banking, mobile payments, mobile life "," mobile community "," mobile marketing "five integrated mobile financial system; actively use the Internet thinking and methods, change product development, business development and marketing mode, such as pay attention to film advertising, TV commercials, such as the implantation of advertising, pay attention to customer experience, Make full use of social interaction with customers, entertainment, intelligent advantages, relying on the domestic huge Internet Guest group, strengthen the large data analysis, with convenient and efficient service experience and the deep integration with the Life service function, increase the strength to cultivate users to use habits, improve the use of viscous users, all customer centered, Improve payment and settlement, transfer remittance convenience and fast.

\section{Suggestions on strategic choice of financial regulatory institutions}

In the internet age, the boundaries of financial services have become more blurred. On the one hand, some Internet financial innovation may be "poly less", from the scale of financial stability, on the other hand, some may be small, but distributed in a large number of individuals and "long tail crowd" there, the most typical is the balance treasure and Peer-to-peer network loans. With the rapid development of the Internet finance industry and the springing up of the emerging Internet financial companies, the huge potential of this industry has been seen, but the events of 2015 have exposed many loopholes, risks and even scams caused by the lack of regulation in the industry. Therefore, Internet finance will also be the focus area of financial supervision in the future. The financial supervision should integrate the large scale and systemically important characteristics of Internet financial business into the macro-prudential management framework, and carry out macro-prudential assessment (MPA) to prevent systemic risk. MPA from capital and leverage, assets and liabilities, liquidity, pricing behavior, asset quality, Crossborder financing risk, credit policy implementation of the seven major aspects of the behavior of financial institutions to guide the multidimensional, the initiative to prevent the elimination of systemic financial risks in a more important position, and strive to improve the financial security lines of defense and risk response mechanism, To strengthen the professionalism, unity and penetration of financial supervision, all financial businesses should be included in the supervision, timely and effective identification and resolution of risks, and the regulation of financial chaos.

Financial supervision should be more optimized level and division of labor, from the angle of financial stability, we should pay more attention to discovering and warning the problems of systemic risk in the process of Internet financial development, while the micro-level problems are more concerned by different levels of supervisors, some of which have little systemic influence, and some Internet financial activities after the Regulation, There should still be some innovative space, that is, financial supervision should strengthen the prevention of systemic risk, strengthen policy guidance, improve the supervision system, create a normative operation, orderly competition, service entities and encourage innovation in the development of the Internet financial situation. 


\section{CONCLUSION}

The rapid development of electronic payment industry has benefited from huge population and market scale, rapid internet trend, especially the rise of E-commerce and the rapid development of Internet finance, with the advent of electronic payment innovation model, the electronic payment service scene expands and popularized rapidly, the era of non-cash electronic payment is accelerating. With the tightening of financial regulation, the policy dividend slowly abate, the competition is intense unceasingly squeezes the industry profit, the third party payment service provider should give full play to the payment mode innovation and the service innovation ability and the superiority, from the multiplex financial service, the new Consumer Ecology Circle Construction, the Crossborder Electronic payment service, the deep vertical profession and so on seeks the breakthrough Commercial banks should fully and accurately grasp the characteristics and trends of internet financial development, face the increasingly fierce cross-border competition in the Internet, actively use the Internet thinking and methods, change product development, business development and marketing mode, give full play to commercial banks as credit intermediary credit advantages, as well as risk prevention and control field of professionalism, Actively promote mobile banking and micro-credit Bank, to create "mobile banking", "mobile payment", "Mobile Life", "mobile community", "mobile marketing" five-integrated mobile financial system, to provide customers with more professional, convenient comprehensive financial solutions. In the internet age, the boundaries of financial services have become more blurred. On the one hand, some Internet financial innovation may be "less poly", from the size of the impact on financial stability, on the other hand, some may be small, but distributed in a large number of individuals and "long tail people" there. Financial supervision should effectively identify and regulate financial chaos, prevent systemic financial risk, create a new situation of internet finance development, which is standard operation, orderly competition, service entity and encouraging innovation.

\section{REFERENCES}

[1] Yan Liu, Jianzheng Yang. The present situation and future development trend of electronic payment in China [J]. E-commerce, 2017 (2): 34-36. (In Chinese)

[2] Benhong Peng, Baiyu Wu. Cross-border search, dynamic capability and open service innovation performance $[\mathrm{J}]$. China Science and Technology Forum, 2017 (10): 33-39. (In Chinese)

[3] Xiaofang Chen, Wencai Huang. An empirical study on the relationship between internal knowledge transformation and individual service innovation behavior in commercial banks [J]. Journal of Jilin University Social Sciences, 2017 (1): 64-73. (In Chinese)

[4] Bo Wang. On the innovation of banking financial services in the internet Financial Times [J]. Journal of Harbin Institute of Finance, 2015, (12): 37-39. (In Chinese)

[5] Hua Cheng. Network externality, heterogeneity of demand and innovation of electronic payment $[\mathrm{J}]$. Economic theory and economy management, 2015, (9): 18-25. (In Chinese)

[6] Qui Zhang. General business model and innovation supervision of electronic payment [J]. Shanghai finance, 2014 (7): 72-76. (In Chinese) 